\title{
Effect of dietary fat type on performance, biochemical indices and fatty acids profile in the blood serum of broiler chickens
}

\author{
K. Burlikowska', A. Piotrowska and R. Szymeczko \\ University of Technology and Life Sciences, Department of Animal Physiology \\ Mazowiecka 28, 85-084 Bydgoszcz, Poland
}

(Received 27 August 2009; revised version 17 March 2010; accepted 16 August 2010)

\begin{abstract}
The aim of the experiment was to compare the effect of different dictary fat sources on performance, biochemical indices and fatty acid profile in the blood scrum of broilers. The study was carried out on 96 male Ross 308 chickens from 1 to 42 day of life, fed diets supplemented with soyabean oil (SO), Nowitol $30(\mathrm{~N})$ and lard $(\mathrm{L})$. The ratio of UFA/SFA in fat sources was: 4.55 $(\mathrm{SO}), 4.27(\mathrm{~N}), 1.75(\mathrm{~L})$. There was no effect of dietary fat on performance indices, protein and fat metabolism parameters, $\mathrm{Ca}, \mathrm{P}$ and chloride concentration in the blood. The highest $(\mathrm{P}<0.05) \mathrm{Mg}$ concentration was found in $\mathrm{N}$ group. A higher percentage $(\mathrm{P}<0.05)$ of SFA $(34.16 \%)$ and lower $(\mathrm{P}<0.05)$ level of PUFA $(54.01 \%)$ was found in chickens from group $\mathrm{L}$ in comparison with broilers from the SO (SFA - 33.18\%, PUFA - 55.84\%) and N (SFA - 33.30\%, PUFA - 55.99\%) groups. The results indicate that performance and biochemical indices were not negatively affected by tested fat sources.
\end{abstract}

KEY WORDS: broiler, dietary fat, performance, blood serum, fatty acids

\section{INTRODUCTION}

In the intensive feeding of poultry, fat is the natural component of the fodder mixtures, an additive increasing their energy value as well as a factor improving the consistency and tastiness of the feed. In the diets for broilers, vegetable fats

\footnotetext{
${ }^{1}$ Corresponding author: e-mail: kasiab@utp.edu.pl
} 
such as soyabean oil and rapeseed oil, as well as animal fats such as beef tallow, bone and poultry fat are used (Zduńczyk et al., 2001). In the recent years there has also been growing interest in lard (Latour et al., 1994; Peebles et al., 1997a,b,c). Studies have shown that birds have the ability to utilize significant amounts of dietary fat as a source of energy; however, the efficiency of its utilization largely depends on the composition of fatty acids (Latour et al., 1994; Scaife et al.,1994; Peebles et al.,1997a,b,c; Dvorin et al., 1998; Zduńczyk et al., 2001; Özdoğan and Akşit, 2003; Shahriar et al., 2007). It was shown that animal fats rich in saturated fatty acids are more difficult to digest in the digestive system of poultry as compared to unsaturated vegetable oils (Dvorin et al., 1998; Zduńczyk et al., 2001). The importance of fat from different sources in the feeding of broilers is analysed not only from the aspect of production effects, but also in the context of human health. There is, indeed, a potential possibility of changing the profile of fatty acids in the carcasses of poultry by a suitable their composition in the diet (Scaife et al., 1994; Dvorin et al., 1998; Crespo and Esteve-Garcia, 2001; Viveros et al., 2009). At the same time the level and type of fat in the diet influence the biochemical parameters of the blood, which are sensitive indicators of the state of health of the animals and reflects the intensity of metabolic processes taking place in their organisms (Ross et al., 1978; Bowes et al., 1989; Meluzzi et al., 1992; Krasnodębska-Depta and Koncicki, 2000).

Researchers have been concerned over the recent years to find solutions for poultry feeding which to support high broiler performance and lower feeding costs. Soyabean oil is the main source of vegetable fat used in poultry feeding because of the favourable fatty acids composition and high content of metabolizable energy (Smulikowska and Rutkowski, 2005), but its cost is relatively high. Nowitol 30 (fat concentrate derived from genetically modified soyabean) and lard are cheaper potential alternative energy sources allowing cutting the feeding costs. However, information on the influence of these two fat sources on biochemical parameters and health status of chickens is scan. Therefore the aim of the study was to compare the effect of Nowitol 30, lard and soyabean oil on performance, selected indices of protein and lipid metabolism, the level of mineral components and profile of fatty acids in the blood serum of broiler chickens.

\section{MATERIAL AND METHODS}

\section{Animals and feeding}

The studies were conducted on 96 male Ross 308 meat-type chickens, coming from a local hatchery. After delivering broilers to an experimental 
hen house they were weighed and randomly assigned to one of the three experimental groups. Each group contained 32 birds in 4 replications ( 8 birds per pen). The broilers were housed in cages with litter-free floor covered with a mat made of cast plastic, in a room with automatically controlled temperature, humidity and air exchange. The birds were provided with continuous light. The rearing was conducted according to the technological recommendations for the breed. During the 6-week experiment all birds were fed ad libitum with isocaloric and isonitrogenous commercial feed based on maize, wheat and soyabean. All chicks were fed starter 1 up to $7 \mathrm{~d}$, starter 2 from 8 to $21 \mathrm{~d}$, grower from 22 to 35 $\mathrm{d}$ and then finisher diets from 36 to $42 \mathrm{~d}$ of life. Water was provided ad libitum by nipple drinkers. All diets were formulated to meet the minimum nutrient requirement for broiler chickens (Smulikowska and Rutkowski, 2005). Diets SO throughout whole experiment were supplemented only with soyabean oil (Table 1$)$. In the starter period (0-21 d) diets $\mathrm{N}$ were supplemented with soyabean oil and Nowitol 30 (vegetable fat concentrate, Nordische Futterfette Carroux, Poland) and diets L with soyabean oil and lard. The only fat sources in grower and finisher periods were Nowitol for diets $\mathrm{N}$ and lard for diets $\mathrm{L}$. The amount of ME from added fat was 3.3, 5.7, 10.8 and $11.1 \%$ of total ME, respectively, in starter 1 and 2, grower and finisher diets. The study was conducted under a research protocol approved by the Local Ethical Committee in Bydgoszcz (Poland).

\section{Data collection}

Body weight (BW) of individual chickens within each replicate group and feed intake per pen were recorded $12 \mathrm{~h}$ after the removal of feed at 21 and $42 \mathrm{~d}$ of age. Feed conversion (FCR) was determined as the ratio between the feed intake and weight gain. European Efficiency Index (EEI) was calculated for each pen replicate as follows:

$\mathrm{EEI}=($ livability $\times$ liveweight, $\mathrm{kg} /$ length of rearing period, days $\times \mathrm{FCR}) \times 100$

The blood for analysis was collected from the pterygoid canal vein on the $42^{\text {nd }}$ day of the experiment after $12 \mathrm{~h}$ of feed deprivation from 12 broilers from each group. The selected chickens were characterized by equalized body weight, most similar to the average body weight of the birds from a given group.

\section{Chemical analysis}

After coagulation, blood samples were centrifuged at $3,000 \mathrm{rpm}$ for $10 \mathrm{~min}$, and the obtained serum were stored in a freezer at $-20^{\circ} \mathrm{C}$ until analyses. In the blood serum the content of total protein, albumin, uric acid, creatinine, aspartate 
Table 1. Calculated nutrient content in the diets

\begin{tabular}{|c|c|c|c|c|c|c|c|c|c|c|c|c|}
\hline \multirow{2}{*}{ Nutrient } & \multicolumn{3}{|c|}{ Starter 1 (0-7 d) } & \multicolumn{3}{|c|}{ Starter $2(8-21 \mathrm{~d})$} & \multicolumn{3}{|c|}{ Grower $(22-35 d)$} & \multicolumn{3}{|c|}{ Finisher (36-42 d) } \\
\hline & $\mathrm{SO}^{1}$ & $\mathrm{~N}^{2}$ & $\mathrm{~L}^{3}$ & SO & $\mathrm{N}$ & $\mathrm{L}$ & $\mathrm{SO}$ & $\mathrm{N}$ & $\mathrm{L}$ & SO & $\mathrm{N}$ & $\mathrm{L}$ \\
\hline Total ME, $\mathrm{MJ} \mathrm{kg}^{-1}$ & 12.62 & 12.64 & 12.64 & 12.74 & 12.73 & 12.74 & 13.20 & 13.21 & 13.20 & 13.30 & 13.31 & 13.31 \\
\hline $\mathrm{ME}$ from $\mathrm{SO}, \mathrm{MJ} \mathrm{kg}^{-1}$ & 0.41 & 0.27 & 0.27 & 0.72 & 0.24 & 0.24 & 1.43 & - & - & 1.47 & - & - \\
\hline $\mathrm{ME}$ from $\mathrm{N}, \mathrm{MJ} \mathrm{kg}^{-1}$ & - & 0.14 & - & - & 0.48 & - & - & 1.44 & - & - & 1.48 & - \\
\hline ME from $\mathrm{L}, \mathrm{MJ} \mathrm{kg}^{-1}$ & - & - & 0.14 & - & - & 0.48 & - & - & 1.44 & - & - & 1.48 \\
\hline Crude protein, $\%$ & 21.10 & 21.00 & 21.00 & 21.00 & 21.00 & 21.10 & 19.90 & 19.9 & 19.9 & 18.90 & 18.90 & 18.90 \\
\hline Lys, \% & 1.18 & 1.18 & 1.18 & 1.12 & 1.12 & 1.12 & 1.12 & 1.12 & 1.12 & 1.00 & 1.00 & 1.00 \\
\hline Met, $\%$ & 0.55 & 0.55 & 0.55 & 0.49 & 0.50 & 0.50 & 0.45 & 0.44 & 0.44 & 0.40 & 0.40 & 0.40 \\
\hline Met + Cys, $\%$ & 0.90 & 0.90 & 0.90 & 0.85 & 0.85 & 0.85 & 0.80 & 0.79 & 0.79 & 0.73 & 0.73 & 0.73 \\
\hline $\operatorname{Trp}, \%$ & 0.25 & 0.25 & 0.25 & 0.25 & 0.25 & 0.25 & 0.24 & 0.24 & 0.24 & 0.23 & 0.23 & 0.23 \\
\hline $\mathrm{Ca}, \%$ & 1.00 & 1.00 & 1.00 & 1.00 & 1.00 & 1.00 & 0.96 & 0.96 & 0.96 & 0.90 & 0.90 & 0.90 \\
\hline $\mathrm{P}$ available, $\%$ & 0.45 & 0.45 & 0.45 & 0.45 & 0.45 & 0.45 & 0.44 & 0.44 & 0.44 & 0.42 & 0.42 & 0.42 \\
\hline
\end{tabular}

${ }^{1} \mathrm{SO}$ - soyabean oil; ${ }^{2} \mathrm{~N}$ - Nowitol; ${ }^{3} \mathrm{~L}$ - lard 
aminotransferase (AST), alanine aminotransferase (ALT), lactic acid dyhydrogenase (LDH), triglycerides (TG), total cholesterol, HDL fraction, calcium (Ca), inorganic phosphorus $(\mathrm{Pi})$, magnesium $(\mathrm{Mg})$ and chlorides $(\mathrm{Cl})$ was determined. All the above mentioned parameters were determined with the help of an Epoll 20 photometer using original Alpha Diagnostics kits. The content of LDL and VLDL lipoprotein fractions in the blood serum was calculated on the basis of Friedewald equation (Friedewald et al., 1972; Peebles et al., 1997a,c). Lipids extraction from blood serum was made by the chloroform-methanol (2:1) as described by Folch et al. (1957). The extracted fatty acids were estrified and methyl esters were analysed by CLARUS $600 \mathrm{GC} / \mathrm{MS}$ PerkinElmer equipped with an Elite-5MS (PerkinElmer) column ( $30 \mathrm{~m}, 0.25 \mathrm{~mm}, 0.5 \mu \mathrm{m}$ film thickness). The analyses were made at the pre-programmed temperature of $140^{\circ} \mathrm{C}(4 \mathrm{~min})-4^{\circ} \mathrm{C} / \mathrm{min}-270^{\circ} \mathrm{C}(5 \mathrm{~min})$. Other parameters were as follows: carrier gas $\mathrm{He} 6.0$ at a flow of $1 \mathrm{ml} / \mathrm{min}$, splitless, feeder $250^{\circ} \mathrm{C}$, transfer line $150^{\circ} \mathrm{C}$, ion source $200^{\circ} \mathrm{C}$, mass scan $(\mathrm{m} / \mathrm{z}) 35-400$. Fatty acids profile in the experimental fat sources was estimated according to the method described above. All analyses were performed in duplicate. Based on the performed analyses the content of saturated fatty acids (SFA), monounsaturated fatty acids (MUFA) and polyunsaturated fatty acids (PUFA) as well as the unsaturated and saturated acids ratio (UFA/SFA) were determined.

\section{Statistical analysis}

The results were analysed statistically using the Statistica 8.0 PL program with one way analysis of variance (ANOVA). The post hoc Duncan test was applied. The significance of differences was set at $\mathrm{P}<0.05$.

\section{RESULTS AND DISCUSSION}

The content of fatty acids is an important criterion in evaluating the use of fat in the intensive feeding of poultry. A profile of fatty acids in the experimental sources of fat is presented in Table 2. The highest content of SFA was found in lard $(36.39 \%)$, definitely the lower percentage of SFA was found in soyabean oil and Nowitol (18.02 and 18.98\%). Among SFA the dominating ones were palmitic (C16:0) and stearic acid (C18:0). The monounsaturated fatty acids in the lard and Nowitol comprised more than $50 \%$ of total fatty acids (TFA), half the content from soyabean oil. The vegetable sources of fat, as compared to the lard, were characterized by a several times higher content of polyunsaturated fatty acids, which in the soyabean oil comprised 55 , and in Nowitol $23 \%$ of TFA. For 
Table 2. Fatty acid profile in dietary fat sources, $\%$

\begin{tabular}{lrrr}
\hline Fatty acid & \multicolumn{3}{c}{ Fat source } \\
\cline { 2 - 4 } & $\mathrm{SO}^{1}$ & \multicolumn{1}{c}{$\mathrm{N}^{2}$} & \multicolumn{1}{c}{$\mathrm{L}^{3}$} \\
\hline $12: 0$ & 0.00 & 0.28 & 3.00 \\
$15: 0$ & 0.00 & 0.85 & 0.08 \\
$16: 0$ & 0.01 & 0.05 & 15.85 \\
$17: 0$ & 10.79 & 11.18 & 1.04 \\
$18: 0$ & 0.22 & 0.19 & 14.74 \\
$20: 0$ & 3.70 & 4.27 & 0.54 \\
$21: 0$ & 0.69 & 0.79 & 0.31 \\
$22: 0$ & 0.31 & 0.30 & 0.06 \\
$23: 0$ & 1.02 & 0.14 & 0.44 \\
$24: 0$ & 0.45 & 0.44 & 0.02 \\
$16: 1$ & 0.82 & 0.48 & 4.33 \\
$18: 1$ & 0.25 & 0.31 & 47.70 \\
$20: 1$ & 25.70 & 55.80 & 1.01 \\
$22: 1$ & 0.24 & 0.45 & 0.35 \\
$24: 1$ & 0.30 & 1.00 & 0.56 \\
$18: 2 \mathrm{n}-6$ & 0.50 & 0.52 & 8.59 \\
$20: 2 \mathrm{n}-6$ & & & 0.29 \\
$\alpha-18: 3 \mathrm{n}-3$ & 48.79 & 21.28 & 0.75 \\
SFA & 0.25 & 0.25 & 36.39 \\
MUFA & & & 53.98 \\
PUFA & 6.00 & 1.46 & 9.63 \\
UFA/SFA & & 18.98 & 1.75 \\
\hline SO & 18.02 & 58.04 &
\end{tabular}

${ }^{1} \mathrm{SO}$ - soyabean oil; ${ }^{2} \mathrm{~N}$ - Nowitol; ${ }^{3} \mathrm{~L}$ - lard

Table 3. Performance indices of broiler chickens

\begin{tabular}{lccc}
\hline \multirow{2}{*}{ Indices } & \multicolumn{3}{c}{ Group } \\
\cline { 2 - 4 } & $\mathrm{SO}^{1}$ & $\mathrm{~N}^{2}$ & $\mathrm{~L}^{3}$ \\
\hline 0-21d & & & \\
body weight gain, $\mathrm{kg}$ & $0.845 \pm 0.03^{6}$ & $0.837 \pm 0.06$ & $0.830 \pm 0.05$ \\
$\mathrm{FCR}^{4}, \mathrm{~kg} k g^{-1}$ & $1.303 \pm 0.01$ & $1.310 \pm 0.01$ & $1.320 \pm 0.01$ \\
mortality, \% & 0.0 & 0.0 & 0.0 \\
EEI $^{5}$ & $324 \pm 11$ & $319 \pm 21$ & $314 \pm 18$ \\
$0-42 d$ & & & \\
body weight gain, $\mathrm{kg}$ & $2.557 \pm 0.12$ & $2.563 \pm 0.09$ & $2.513 \pm 0.25$ \\
FCR $^{4}, \mathrm{kgkg}^{-1}$ & $1.717 \pm 0.02$ & $1.723 \pm 0.02$ & $1.690 \pm 0.02$ \\
mortality, \% & 0.0 & 0.0 & 0.0 \\
EEI $^{5}$ & $360 \pm 14$ & $360 \pm 17$ & $360 \pm 38$ \\
\hline
\end{tabular}

${ }^{1} \mathrm{SO}$ - soyabean oil; ${ }^{2} \mathrm{~N}$ - Nowitol; ${ }^{3} \mathrm{~L}$ - lard; ${ }^{4} \mathrm{FCR}$ - feed conversion ratio; ${ }^{5} \mathrm{EEI}$ - European Efficiency Index; ${ }^{6}$ data are presented as means $\pm \mathrm{SD}$ 
all the experimental fats, linoleic acid (C18:2 n-6) was about $90 \%$ of PUFA. From the nutritional point of view, the vegetable sources of fat used in the experiment were characterized by a more beneficial UFA/SFA ratio as compared to the animal fat (Zduńczyk et al., 2001).

The effects of inclusion of dietary fat sources in chicken diets on performance are summarized in Table 3 . The results indicate that body weight gain, FCR and EEI value were not affected significantly by the supplemented fat sources. This is in agreement with data reported by Crespo and Esteve-Garcia (2001) and Viveros et al. (2009) in studies comparing PUFA and SFA fat sources. However, Atteh and Leeson (1983) reported that saturation degree of a dietary fat can influence feed intake, weight gain and FCR which results from better availability of energy from unsaturated fatty acids. Moreover, digestion and absorption of dietary fat depends also on the age of birds. It is especially marked in case of saturated animal fats, which are particularly poorly digested initially and their utilization increases gradually to $8 \mathrm{wk}$ of age (Krogdahl, 1985). In the present study it was also noted that in the period from 0 to $21 \mathrm{~d}$ the vegetable fat sources rich in unsaturated fatty acids (Table 2) resulted in insignificant higher BW gain and better feed efficiency compared to saturated animal fat - lard.

Protein and lipid metabolism indices determined in the experiment, the activity of selected enzymes and the level of mineral components in the blood serum of chickens are given in Table 4 . There was no significant influence of the dietary fat sources on the content of total protein, albumin, uric acid, creatinine, and activity

Table 4. Biochemical indices in the blood serum of broilers chickens

\begin{tabular}{|c|c|c|c|c|}
\hline \multirow{2}{*}{ Item } & \multicolumn{3}{|c|}{ Group } & \multirow{2}{*}{$\mathrm{P}<$} \\
\hline & $\mathrm{SO}^{1}$ & $\mathrm{~N}^{2}$ & $\mathrm{~L}^{3}$ & \\
\hline Total protein, $\left.\mathrm{g}\right|^{-1}$ & $35.60^{4} \pm 3.70$ & $37.00 \pm 3.50$ & $35.00 \pm 3.30$ & NS \\
\hline Albumins, $\mathrm{g}^{\mathbf{l}^{-1}}$ & $14.80 \pm 1.40$ & $15.80 \pm 1.80$ & $14.30 \pm 1.90$ & NS \\
\hline Uric acid, mmoll $\mathrm{l}^{-1}$ & $0.24 \pm 0.07$ & $0.23 \pm 0.05$ & $0.23 \pm 0.08$ & NS \\
\hline Creatinine, $\mu \mathrm{mol} \cdot l^{-1}$ & $25.64 \pm 4.42$ & $24.75 \pm 4.42$ & $24.75 \pm 5.30$ & NS \\
\hline AST, $U \cdot 1^{-1}$ & $254.58 \pm 33.91$ & $287.08 \pm 45.11$ & $275.83 \pm 61.15$ & NS \\
\hline ALT, $U \cdot 1^{-1}$ & $14.08 \pm 5.05$ & $13.83 \pm 2.62$ & $13.25 \pm 4.75$ & NS \\
\hline $\mathrm{LDH}, \mathrm{IU}^{-1}$ & $1985.00 \pm 522.86$ & $2363.67 \pm 817.18$ & $1784.75 \pm 638.71$ & NS \\
\hline Trigliceride, $\mathrm{mmol}^{-\mathrm{l}^{-1}}$ & $0.73 \pm 0.11$ & $0.79 \pm 0.15$ & $0.78 \pm 0.14$ & NS \\
\hline Total cholesterol, $\mathrm{mmol}^{-1}$ & $3.67 \pm 0.71$ & $3.76 \pm 0.36$ & $3.53 \pm 0.37$ & NS \\
\hline \multicolumn{5}{|l|}{$m m o l l^{t}$} \\
\hline HDL & $1.75 \pm 0.35$ & $1.84 \pm 0.15$ & $1.77 \pm 0.15$ & NS \\
\hline LDL & $1.59 \pm 0.53$ & $1.56 \pm 0.28$ & $1.41 \pm 0.40$ & NS \\
\hline VLDL & $0.33 \pm 0.05$ & $0.36 \pm 0.07$ & $0.35 \pm 0.06$ & NS \\
\hline calcium & $2.46 \pm 0.35$ & $2.50 \pm 0.41$ & $2.43 \pm 0.38$ & NS \\
\hline phosphorus & $2.17 \pm 0.68$ & $2.40 \pm 0.13$ & $2.34 \pm 0.15$ & NS \\
\hline magnesium & $1.01^{\mathrm{a}} \pm 0.06$ & $1.14^{b} \pm 0.09$ & $1.06^{\mathrm{a}} \pm 0.12$ & 0.05 \\
\hline chloride & $104.42 \pm 5.78$ & $106.17 \pm 3.88$ & $101.58 \pm 4.89$ & NS \\
\hline
\end{tabular}

${ }^{1} \mathrm{SO}$ - soyabean oil; ${ }^{2} \mathrm{~N}$ - Nowitol; ${ }^{3} \mathrm{~L}$ - lard; ${ }^{4}$ data are presented as means $\pm \mathrm{SD}$

a.b means in the rows with different letters differ significantly at $\mathrm{P}<0.05$ 
of AST, ALT and LDH in the blood serum of the birds. The values of these parameters, except for creatinine, were within the wide range of reference values specified for chickens (Ross et al., 1978; Bowes et al., 1989; Meluzzi et al., 1992). The concentration of creatinine, the indicator of muscular metabolism, in the blood of 42-day-old experimental broilers was twice lower (24.75 to $\left.25.64 \mu \mathrm{mol}^{-1}\right)$ than the values $\left(52.30 \mu \mathrm{mol}^{-1} \mathrm{l}^{-1}\right)$ obtained by Bowes et al. (1989). In the study cited above the blood was collected from birds that were not starved earlier. It may be the cause for the higher creatinine content in comparison to the results of the present experiment. Similar level of creatinine in the blood serum, like other indicators of protein metabolism, is evidence of the equalized intensification of protein metabolism in the bodies of the experimental broilers. In the available literature there are no data concerning the influence of dietary fat sources on the protein metabolism indices in the blood of broiler chickens. It should be noticed that the studies by Dvorin et al. (1998) and Özdoğan and Akşit (2003) did not show the influence of fat type and level of its saturation on the retention of nitrogen in chickens and the content of protein in the muscles. The lack of significant differences between the groups with regard to the LDH activity indicates an equalized carbohydrates metabolism level in the organisms of broilers fed isoprotein and isocaloric diets supplemented with soyabean oil, Nowitol and lard.

The experiment showed a statistically significant $(P<0.05)$ influence of the fat source on the magnesium content in the blood scrum of the birds (Table 4). A significantly higher level of this mineral was shown in chickens fed a diet with Nowitol $\left(1.14 \mathrm{mmol}^{-1}\right)$ as compared to those fed with mixtures including soyabean oil $\left(1.01 \mathrm{mmol}^{-1} \mathrm{l}^{-1}\right)$ and lard $\left(1.06 \mathrm{mmol}^{-\mathrm{l}^{-1}}\right)$. The type of fat used did not influence significantly the content of calcium, phosphorus and chlorides, and the level of all determined minerals was close to the physiological values specified for 42-day-old chickens (Ross et al., 1978; Bowes et al., 1989; Meluzzi et al., 1992; Krasnodębska-Depta and Koncicki, 2000). The wide range of physiological norms and high changeability in the content of minerals in the blood of the birds is caused by a number of factors, including the level and type of fat in the diet. According to Atteh and Leeson (1983) in the intestinal digesta in the presence of saturated fatty acids, particularly palmitic and stearic along with calcium and magnesium insoluble soaps are formed, which decrease the absorption of minerals as well as the availability of fatty acids in poultry. It was also shown that the least amount of soaps is formed in the presence of oleic acid (Atteh and Leeson, 1983), which is most likely the reason for significantly higher levels of magnesium in the blood serum of the experimental birds fed the diet with Nowitol.

The different kinds of fat used in the present study did not influence significantly the level of fat metabolism indices (Table 4). The content of triglycerides and total 
cholesterol in the blood serum of the birds of all the experimental groups was rather similar and consistent with the physiological norms specified for 42-day-old broiler chickens (Bowes et al., 1989; Meluzzi et al., 1992; Krasnodębska-Depta and Koncicki, 2000). It is widely known that individual fractions of lipoproteins play various roles in the transport of lipids. HDL, beneficial for the body and conditioning the transport of cholesterol from the peripheral tissues to the liver, is the main fraction of lipoproteins in the blood of the birds (Peebles et al., 1997c). In the present study the content of HDL fraction was from 48 to $50 \%$ of the total cholesterol. Approximately $10 \%$ of total cholesterol in the male broilers blood was the VLDL fraction, which, according to Grunder and Chambers (1988), highly correlates with abdominal fat and is a good indicator of fat deposition in birds.

Table 5 presents a profile of the fatty acids in the blood serum of the experimental broilers. The results show that the content of fatty acids in the sources of fat used had a direct effect on their profile in the serum. In chickens fed the diet supplemented with lard, a significantly higher $(\mathbf{P}<0.05)$ level of saturated fatty acids was shown, and at the same time a significantly lower

Table 5. Fatty acid profile in the blood serum of broiler chickens, $\%$

\begin{tabular}{lrrrl}
\hline \multirow{2}{*}{ Fatty acid } & \multicolumn{1}{c}{ SO } & \multicolumn{1}{c}{ Group } & \multicolumn{1}{c}{$\mathrm{N}^{3}$} & $\mathrm{P}<$ \\
\cline { 2 - 5 } $16: 0$ & $14.52^{\mathrm{a}} \pm 1.35$ & $14.57 \pm 0.34$ & $15.34 \pm 1.02$ & $\mathrm{NS}$ \\
$18: 0$ & $12.96 \pm 1.24$ & $12.59 \pm 0.84$ & $12.90 \pm 0.48$ & $\mathrm{NS}$ \\
$20: 0$ & $1.11 \pm 0.48$ & $1.08 \pm 0.33$ & $1.02 \pm 0.27$ & $\mathrm{NS}$ \\
$22: 0$ & $1.18 \pm 0.25$ & $1.30 \pm 0.25$ & $1.21 \pm 0.25$ & $\mathrm{NS}$ \\
$23: 0$ & $1.28 \pm 0.27$ & $1.42 \pm 0.27$ & $1.32 \pm 0.27$ & $\mathrm{NS}$ \\
$24: 0$ & $2.13 \pm 0.63$ & $2.33 \pm 0.43$ & $2.36 \pm 0.46$ & $\mathrm{NS}$ \\
$16: 1$ & $0.89^{\mathrm{a}} \pm 0.31$ & $0.68^{\mathrm{b}} \pm 0.16$ & $0.94^{\mathrm{a}} \pm 0.19$ & 0.05 \\
$18: 1$ cis & $7.08^{\mathrm{ab}} \pm 0.91$ & $6.66^{\mathrm{b}} \pm 0.71$ & $7.56^{\mathrm{a}} \pm 0.84$ & 0.05 \\
$18: 1$ trans & $1.11^{\mathrm{a}} \pm 0.11$ & $1.29^{\mathrm{b}} \pm 0.13$ & $1.35^{\mathrm{b}} \pm 0.12$ & 0.05 \\
$20: 1$ & $0.50 \pm 0.09$ & $0.53 \pm 0.08$ & $0.51 \pm 0.09$ & $\mathrm{NS}$ \\
$22: 1$ & $0.64 \pm 0.13$ & $0.70 \pm 0.14$ & $0.65 \pm 0.14$ & $\mathrm{NS}$ \\
$24: 1$ & $0.77 \pm 0.14$ & $0.85 \pm 0.14$ & $0.82 \pm 0.14$ & $\mathrm{NS}$ \\
$18: 2 \mathrm{n}-6$ & $41.87^{\mathrm{a}} \pm 2.48$ & $39.84^{\mathrm{b}} \pm 1.36$ & $38.85^{\mathrm{b}} \pm 1.17$ & 0.05 \\
$\gamma-18: 3 \mathrm{n}-6$ & $0.18 \pm 0.03$ & $0.20 \pm 0.02$ & $0.19 \pm 0.01$ & $\mathrm{NS}$ \\
$20: 2 \mathrm{n}-6$ & $0.87 \pm 0.13$ & $0.85 \pm 0.08$ & $0.84 \pm 0.10$ & $\mathrm{NS}$ \\
$20: 3 \mathrm{n}-6$ & $1.27 \pm 0.20$ & $1.17 \pm 0.15$ & $1.24 \pm 0.25$ & $\mathrm{NS}$ \\
$20: 4 \mathrm{n}-6$ & $7.76^{\mathrm{a}} \pm 1.03$ & $9.40^{\mathrm{b}} \pm 0.86$ & $8.52^{\mathrm{a}} \pm 1.14$ & 0.05 \\
$22: 2 \mathrm{n}-6$ & $0.67 \pm 0.14$ & $0.73 \pm 0.14$ & $0.68 \pm 0.14$ & $\mathrm{NS}$ \\
$\alpha-18: 3 \mathrm{n}-3$ & $0.76 \pm 0.14$ & $0.83 \pm 0.10$ & $0.83 \pm 0.12$ & $\mathrm{NS}$ \\
$20: 5 \mathrm{n}-3$ & $1.02 \pm 0.18$ & $1.01 \pm 0.08$ & $1.14 \pm 0.19$ & $\mathrm{NS}$ \\
$22: 6 \mathrm{n}-3$ & $1.43^{\mathrm{a}} \pm 0.16$ & $1.96^{\mathrm{c}} \pm 0.31$ & $1.73^{\mathrm{b}} \pm 0.28$ & 0.05 \\
SFA & $33.18^{\mathrm{a}} \pm 1.30$ & $33.30^{\mathrm{a}} \pm 0.91$ & $34.16^{\mathrm{b}} \pm 0.49$ & 0.05 \\
MUFA & $10.98^{\mathrm{ab}} \pm 1.19$ & $10.71^{\mathrm{b}} \pm 0.78$ & $11.83^{\mathrm{a}} \pm 1.22$ & 0.05 \\
PUFA & $55.84^{\mathrm{a}} \pm 2.35$ & $55.99^{\mathrm{a}} \pm 1.29$ & $54.01^{\mathrm{b}} \pm 1.43$ & 0.05 \\
\hline
\end{tabular}

${ }^{1} \mathrm{SO}$ - soyabean oil; ${ }^{2} \mathrm{~N}$ - Nowitol; ${ }^{3} \mathrm{~L}$ - lard; ${ }^{4}$ data are presented as means $\pm \mathrm{SD}$

a,b means in the rows with different letters differ significantly at $\mathrm{P}<0.05$ 
$(\mathrm{P}<0.05)$ level of polyunsaturated fatty acids as compared to the chickens fed diets with vegetable fats. The main saturated fatty acids in the blood of all the experimental birds, similarly to the fat in the diets, were palmitic and stearic acids. Among PUFA, which formed more than half of the TFA, linoleic acid definitely dominated. Its significantly $(\mathbf{P}<0.05)$ higher content was found in the blood of the birds from SO group, which is connected with its several times higher level in soyabean oil as compared to lard and Nowitol (Table 2). It should be marked that in animals, linoleic acid (C18:2 n-6) and linolenic acid (C18:3 n-3) are considered to be the essential fatty acids. The lack of proper enzymatic systems makes their endogenous synthesis in the organism impossible (Zduńczyk et al., 2001). In the blood serum there were significant amounts of arachidonic acid (C 20:4 n-6). Its content in the sum of fatty acids ranged from 7.76 to $9.40 \%$ and was significantly $(\mathrm{P}<0.05)$ the highest in the birds fed the diet with Nowitol. In the blood, similarly to the experimental sources of fat, among the monounsaturated fatty acids oleic acid (C18:1 cis) dominated, comprising 60\% of MUFA. In the available literature no data were found concerning the influence of the source of fat on the profile of fatty acids in the serum of birds. Numerous studies show, however, that the type and level of fat used and composition of fatty acids in the diet influence the digestibility of the fat and absorption of fatty acids, the level of lipid metabolism indices in the blood and the profile of fatty acids in the tissues (Scaife et al., 1994; Peebles et al., 1997a,c; Dvorin et al., 1998; Özdoğan and Akşit, 2003; Viveros at al., 2009). In the cited papers the beneficial influence of vegetable fat is underlined. Those fats with a higher content of unsaturated fatty acids reduce the level of cholesterol, the lipoprotein LDL and VLDL fractions, at the same time increasing the content of HDL fraction in the blood of the birds.

\section{CONCLUSIONS}

In conclusion, the study did not show any significant influence of the dietary fat sources on the performance indices, parameters of lipid and protein metabolism, the activity of aspartate aminotransferase, alanine aminotransferase, lactic acid dehydrogenase and concentration of $\mathrm{Ca}$, inorganic $\mathrm{P}$ and $\mathrm{Cl}$ in the blood of 42day-old male broiler chickens. The type of fat used influenced only the content of $\mathrm{Mg}$ in the blood of the birds. The results indicate a similar level of metabolic changes in the organisms of chickens fed isocaloric and isoprotein diets with soyabean oil, Nowitol and lard. However, the composition of fatty acids in the experimental fat sources influenced significantly the profile of fatty acids in the blood of the birds. In chickens fed diets with vegetable fats, the significantly lower content of saturated fatty acids and higher level of polyunsaturated fatty acids was demonstrated. 


\section{REFERENCES}

Attch J.O., Lecson S., 1983. Effects of dietary fatty acids and calcium levels on performance and mineral metabolism of broiler chickens. Poultry Sci. 62, 2412-2419

Bowes V.A., Julian R.J., Stirtzinger T., 1989. Comparison of serum biochemical profiles of male broilers with female broilers and white leghorn chickens. Can. J. Vet. Res. 53, 7-11

Crespo N., Esteve-Garcia E., 2001. Dietary fatty acids profile modifies abdominal fat deposition in broiler chickens. Poultry Sci. 80, 71-78

Dvorin A., Zoref Z., Mokady S., Nitsan Z., 1998. Nutritional aspects of hydrogenated and regular soybean oil added to diets of broiler chickens. Poultry Sci. 77, 820-825

Folch H., Less M., Stancy H.A., 1957. A simple method for isolation and purification of total lipids from animal tissues. J. Biol. Chem. 226, 497-499

Friedewald W.T., Levy R.I., Fredrickson D.S., 1972. Estimation of the concentration of low-density lipoprotein cholesterol in plasma, without use of the preparative ultracentrifuge. Clin. Chem. $18,499-502$

Grunder A.A., Chambers J.R., 1988. Genetic parameters of plasma very low density lipoproteins, abdominal fat lipase, and protein, fatness, and growth traits of broiler chickens. Poultry Sci. 67, 183-190

Krasnodębska-Depta A., Koncicki A., 2000. Physiological values of selected serum biochemical indices in broiler chickens (in Polish). Med. wet. 56,456-460

Krogdahl A., 1985. Digestion and absorption of lipids in poultry. J. Nutr. 115, 675-685

Latour M.A., Peebles E.D., Boyle C.R., Brake J.D., 1994. The effects of dietary fat on growth performance, carcass composition, and feed efficiency in the broiler chick. Poultry Sci. 73, 1362-1369

Meluzzi A., Primiceri G., Giordani R., Fabris G., 1992. Determination of blood constituents reference values in broilers. Poultry Sci. 71, 337-345

Özdoğan M., Akşit M., 2003. Effects of fecds containing different fats on carcass and blood parameters of broilers. J. Appl. Poultry Res. 12, 251-256

Pecbles E.D., Cheancy J.D., Brake J.D., Boyle C.R., Latour M.A., 1997a. Effects of added lard on body weight and scrum glucose and low density lipoprotein cholesterol in randombred broiler chickens. Poultry Sci. 76, 29-36

Peebles E.D., Cheaney J.D., Brake J.D., Boyle C.R., Latour M.A., McDaniel C.D., 1997b. Effects of added lard fed to broiler chickens during the starter phase. 1. Body and selected organ weights, feed conversion, hematology, and serum glucose. Poultry Sci. 76, 1641-1647

Peebles E.D., Cheaney J.D., Brake J.D., Boyle C.R., Latour M.A., McDaniel C.D., 1997c. Effects of added lard fed to broiler chickens during the starter phase. 2. Serum lipids. Poultry Sci. 76, $1648-1654$

Ross J.G., Christie G., Halliday W.G., 1978. Haematological and blood chemistry „comparison values" for clinical pathology in poultry. Vet. Rec. 102, 29-31

Scaife J.R., Moyo J., Galbraith H., Michie W., Campbell V., 1994. Effect of different dietary supplemental fats and oils on the tissue fatty acid composition and growth of female broilers. Brit. Poultry Sci. 35, 107-118

Shahriar H.A., Rezaei A., Lak A., Ahmadzadeh A., 2007. Effect of dietary fat sources on blood and tissue biochemical factors of broiler. J. Anim. Vet. Adv. 6, 1304-1307

Smulikowska S., Rutkowski A., 2005. Nutrient Recommendations and Nutritive Value of Feedstuffs. Nutritional Standards for Poultry (in Polish). The Kielanowski Institute of Animal Physiology and Nutrition (Editor). Jabłonna (Poland), pp. 136 
Viveros A., Ortiz L.T., Rodríguez M.L., Rebolé A., Alzueta C., Arija I., Centeno C., Brenes A., 2009. Interaction of dietary high-oleic-acid sunflower hulls and different fat sources in broiler chickens. Poultry Sci. 88, 141-151

Zduńczyk Z., Jankowski J., Koncicki A. (Editors), 2001. Fats in Poultry Feeding. Selected Problems (in Polish). Editor: University of Warmia and Mazury, Olsztyn (Poland), pp. 85 